\title{
Herbivory among habitats on the Neotropical tree Cnidoscolus quercifolius Pohl. in a seasonally deciduous forest
}

\author{
Coelho, MS. ${ }^{a}$, Belmiro, MS. ${ }^{a}$, Santos, $J C .^{b}$ and Fernandes, GW. ${ }^{a^{*}}$ \\ ${ }^{a}$ Laboratório de Ecologia Evolutiva e Biodiversidade, Departamento de Biologia Geral, Instituto de Ciências Biológicas, \\ Universidade Federal de Minas Gerais - UFMG, Av. Antônio Carlos, 6627, Pampulha, \\ CEP 30161-970, Belo Horizonte, MG, Brazil

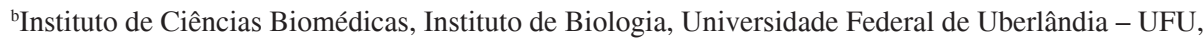 \\ Campus Umuarama, Rua Ceará, s/n, Bloco 2D, Uberlândia, MG, Brazil \\ *e-mail: gw.fernandes@gmail.com
}

Received June 14, 2011 - Accepted August 24, 2011 - Distributed August 31, 2012

(With 3 figures)

\begin{abstract}
Our goal was to identify herbivory patterns from two insect guilds associated with Cnidoscolus quercifolius in a tropical deciduous forest in northeastern Brazil. We sampled four different habitats: (1) forest edge, (2) mesic (near to the perennial water source), (3) forest interior and (4) rupestrian fields. Habitat edge had lower leaf damage than rupestrian, mesic and forest interior habitats. Nevertheless, abundance of galls at the edge habitat was higher than at mesic, forest interior and/or rupestrian habitats. There was no difference in gall mortality by natural enemies among the four habitats sampled, demonstrating the absence of any influence of top-down controls related to abundance of galls. Trophic relationships were not related to the patterns of distribution among habitats of two insect herbivorous guilds associated with $C$. quercifolius. Our results demonstrated that environmental heterogeneity of dry forests can significantly alter important ecological interactions and experimental studies are needed to better understand the mechanisms responsible for differences in herbivory among habitats.
\end{abstract}

Keywords: Caatinga, galling insects, herbivory.

\section{Herbivoria entre habitats em uma árvore neotropical Cnidoscolus quercifolius Polh. em uma floresta estacional decidual}

\begin{abstract}
Resumo
Nosso objetivo foi identificar os padrões de herbivoria de duas guildas de insetos herbívoros associadas à Cnidoscolus quercifolius, em uma floresta estacional seca do nordeste do Brasil. Foram amostrados quatro diferentes habitats: (1) borda florestal; (2) mésico (próximo a uma fonte de água perene); (3) interior florestal, e (4) rupestre. O habitat borda apresentou uma quantidade de dano foliar inferior aos habitats rupestre, mésico e interior florestal. Diferentemente, a abundância de galhas no habitat borda foi superior aos habitats mésico, interior florestal e rupestre. Não houve diferença na mortalidade de galhas por inimigos naturais entre os quatro habitats, o que revela ausência de influência de controles top-down relacionados à abundância de galhas. Relações tróficas não parecem influenciar os padrões de distribuição entre habitats das duas guildas de insetos herbívoros associadas à C. quercifolius. Nossos resultados demonstram que a heterogeneidade ambiental de florestas secas pode alterar significativamente importantes interações ecológicas e que trabalhos experimentais são necessários para uma melhor compreensão dos mecanismos responsáveis pelas diferenças nas taxas de herbivoria entre habitats.
\end{abstract}

Palavras-chave: Caatinga, insetos galhadores, herbivoria. 


\section{Introduction}

Insects make up more than half of biodiversity on the planet and represent the most important link between plants and vertebrates (Gaston and Hudson, 1994; Heywood, 1995). Among the insect guilds, the herbivores have an important role in maintaining the diversity and energy flow (Janzen, 1987; Mulder et al., 1999; Belovsky and Slade, 2003; Carson and Root, 2009). Herbivores may prevent high recruitment rates of some plant species allowing coexistence of higher arboreal species diversity in tropical forests (Janzen, 1970; Connell et al., 1984). Furthermore, the association between herbivorous insects and their host plants originated a series of adaptations such as chemical, mechanical, and phenological defenses (Herms and Mattson, 1992; Coley and Barone, 1996; Strauss and Agrawal, 1999). Due to their role in maintaining the diversity, many studies have tried to explain the patterns and mechanisms related to distribution of herbivorous among habitats in several ecosystems (e.g., Root, 1973; Fernandes and Price, 1988; Lewinsohn et al., 2005; Ribeiro and Basset, 2007; Wirth et al., 2008).

On a regional scale, tropical forests have a higher rate of leaf losses caused by herbivores than temperate forests. This pattern may have resulted from a greater herbivores biomass in tropical forests and more host plants species (Coley and Barone, 1996; Lewinsohn and Roslin, 2008). Among tropical forests, the dry forests have higher herbivory rates mainly due to low defense mechanisms in their ephemeral leaves (Landsberg and Ohmart, 1989; Coley and Barone, 1996). At a local scale, a combination of resource availability (bottom-up) and predator pressure (top-down) seems to define abundance of herbivores and damage (Gratton and Denno, 2003; Cornelissen and Stiling, 2009). However, the ecological forces that control either resource availability or predator abundance vary according to habitat, possibly due to abiotic conditions (e.g. soil features, hygrothermal stress), biotic conditions (e.g. density and vegetation richness) or both (e.g. primary production) (Root, 1973; Fernandes and Price, 1988; McNaughton et al., 1989; Wright and Samways, 1996,1998; Blanche, 2000; Mendonça, 2001; CuevasReyes et al., 2004; Lewinsohn et al., 2005; Ribeiro and Basset, 2007; Wirth et al., 2008). Additionally, herbivores may respond to habitat in different ways according to the trophic guild to which they belong. Endogenous might not be directly affected by secondary compounds, being able to manipulate them for their own benefit, whereas galling insects concentrate secondary compounds in their peripheral tissues of the gall but the larval cameras are kept secondary compounds-free. Thus, galling insects avoid natural enemies and benefit from an environment rich in nutrients (Price et al., 1987). Free-feeding insects, on the other hand, lack such adaptations, and might be more susceptible to secondary compounds and mechanical defenses. Therefore, in the same ecosystem, herbivore populations might exhibit different patterns, depending on the ecological forces that are operating in each habitat and the guild that they belong to (Price, 1998).

The northeast of Brazil is the region where there is a greater area of deciduous forests or dry forests. This ecosystem is called Caatinga and is formed by an arboreal (8-12 m), shrub (5-8 m) and herbaceous vegetations (up to $2 \mathrm{~m}$ ) (Rizzini, 1979). The aim of this study was to describe herbivory patterns in Cnidoscolus quercifolius Polhem. in four different habitats from a tropical dry forest in northeast Brazil and test the hypothesis that Cnidoscolus quercifolius individuals suffer different herbivory rates according to the habitat in consequence of hydrothermal stress (Fernandes and Price, 1988). C. quercifolius Pohl (Euphorbiaceae) known as "faveleira" is a deciduous species, heliophytic, which occurs in xerophytic woods and exhibits irregular dispersion. The tree supports extreme heat, drought and solar radiation (Maia, 2004). Its spines or thorns function as adaptations to minimize the transpiration rate and secrete an urticating substance that when introduced into the skin, cause a painful inflammation, which is important to avoid browsing (Ribeiro Filho et al., 2007). The species has been used in reforestation of eroded areas of different soil habitats in the Caatinga. C. quercifolius also has high economic value to be used as a food source for local populations and livestock (Ribeiro Filho et al., 2007). For these reasons, C. quercifolius is an appropriate ecological model to test hypothesis related to differences in herbivory among habitats.

\section{Material and Methods}

\subsection{Study area}

The study was carried out at Parnamirim town, located in Pernambuco state ( $8^{\circ} 79^{\prime}$ 00” $\mathrm{S}$ and $39^{\circ} 57^{\prime} 00^{\prime}$ ' W). The climate is BSh (semi-arid and hot), according to Köppen classification, with average annual temperature of $26{ }^{\circ} \mathrm{C}$ and precipitation of $569 \mathrm{~mm}$, and the rainy season is concentrated between January and April. The local vegetation is represented by a hyperxerophilous Caatinga, with deciduous forest patches presenting areas with podzol, latosol litholic and bruno-non-calcareous soils (Silva et al., 2000).

\subsection{Experimental design}

In April 2010, 20 individuals of C. quercifolius were arbitrarily sampled in four different habitats from a hyperxerophilous caatinga in Parnamirim: (1) forest edge, (2) mesic (near to the perennial water source), (3) forest interior, (4) rupestrian (rupestrian outcrop); totaling 80 individuals. We collected five branches in each individual, and placed them inside labeled plastic bags, and then took them to the laboratory. One leaf per branch were randomly selected ( $\mathrm{n}=5$ leaves per individual; 400 leaves total) and we recorded (1) leaf area lost (free-feeding herbivores), (2) gall abundance, (3) gall mortality. All galls were opened for observation of the factors associated with mortality of the galling organism. The number of galls dead was recorded for each leaf. The factors included hymenopteran parasitoids, 
lepidopteran larvae, and predation by chewing insects and causes related to desiccation. To assess the rates of leaf area removed, the leaves were scanned and the areas measured in the software Image Tool (University of Texas Health Science Center at San Antonio, San Antonio, TX, USA).

\subsection{Data analysis}

To test the hypothesis that $C$. quercifolius individuals suffer different herbivory damage according to the habitat, we used Kruskal-Wallis test. The four habitats: (1) forest edge, (2) forest interior, (3) rupestrian, (4) mesic, represented the explanatory variables while (1) number of galls, (2) leaf area lost and (3) mortality represented the response variables. When the test results indicated differences among the explanatory variables $(\mathrm{p}<0.05)$, Dunn's post hoc test was used to detect the variation source (Zar, 1999).

\section{Results and Discussion}

The Edge habitat (Mean: $5.76 \pm 0,21 \mathrm{SE} ; \mathrm{n}=100$ ) exhibited a lower percentage of leaf area lost to herbivores than mesic (Mean: $9.95 \pm 1.01 \mathrm{SE} ; \mathrm{n}=100$ ), forest interior (Mean: $11.12 \pm 1.06 \mathrm{SE} ; \mathrm{n}=100)$ and/or rupestrian habitats (Mean: $15.9 \pm 1.43 \mathrm{SE} ; \mathrm{n}=100)(K=34.16$; $\mathrm{DF}=3 ; \mathrm{p}=0.01 ; \mathrm{n}=400)$ (Figure 1$)$. Several studies have reported the susceptibility of free-feeding insects to the hygrothermal stress to explain the higher incidence on wetlands than in xeric habitats (Fernandes and Price, 1988, 1992; Preszler and Price, 1988; Fernandes and Lara, 1993; Price et al., 1998; Blanche, 2000; Björkman, 2000; Blanche and Ludwig, 2001; Lara et al., 2002; Veldtman and Mcgeoch, 2003; Cuevas-Reyes et al., 2004). Our results support this hypothesis as the desiccating factors are more amenable in mesic and interior forest habitats, causing higher herbivory rates by chewing insects on C. quercifolius individuals. C. quercifolius located at rupestrian habitat are more abundant (MSCoelho personal observation). According to the resources concentration hypothesis, abundant populations of plants are associated
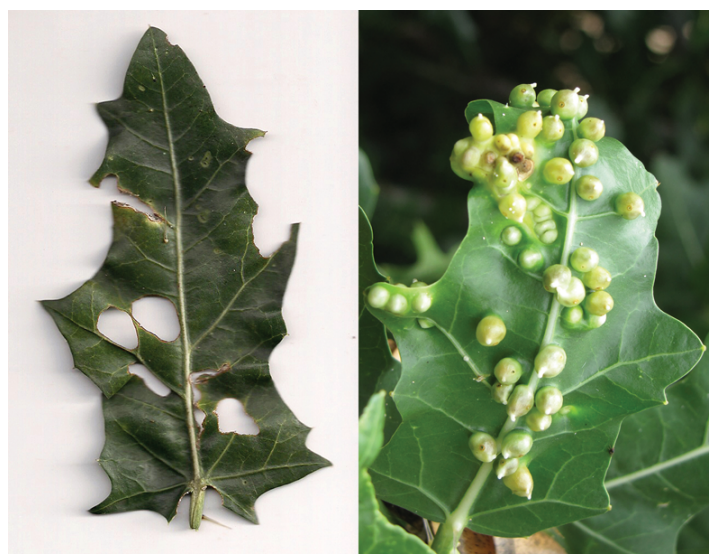

Figure 1. Cnidoscolus quercifolius leaves with damage caused by free-feeding insects and attacked by unidentified Cecidomyiidae species from a seasonally deciduous forest, northeastern Brazil. with higher insects' richness and, consequently leaf area losses (Root, 1973; Gonçalves-Alvim and Fernandes, 2001; Cuevas-Reyes et al., 2004). Moreover, populations immersed in diverse communities have lower herbivory rates from those located in less diverse communities (Andow, 1991; Jactel and Brockerhoff, 2007). The rupestrian habitat is floristically less diverse with fewer tree species (MSCoelho personal observation). Therefore, the high C. quercifolius abundance and the low diversity in rupestrian habitats reinforce the pattern found. Only the rupestraian habitat exhibited herbivory loss (14.2\%) similar to the tropical dry forests (Coley and Barone, 1996). The other habitats sampled exhibited herbivory losses $(11 \%)$ similar to those detected in wet forests (Coley and Barone, 1996). These results reinforce the strong influence of the habitat in the herbivory patterns at tropical dry forests.

The species $C$. quercifolius hosts a conical, green and hairless gall species, with only one chamber induced by an insect belonging to the Cecidomiidae family (Mean: $4.4 \pm 0.2 \mathrm{SE} ; \mathrm{n}=100$ ) (Figure 2). There was a higher abundance of galls at the edge habitat (Mean: 7. 56 $\pm 1.22 \mathrm{SE}$; $\mathrm{n}=100$ ) than mesic (Mean: $3.85 \pm 0.9$ SE; $\mathrm{n}=100$ ), forest interior (Mean: $2.37 \pm 0.37 \mathrm{SE} ; \mathrm{n}=100)$ and rupestrian habitats (Mean: $2.61 \pm 0.49 \mathrm{SE} ; \mathrm{n}=100)(K=12.56$; $\mathrm{DF}=3$; $\mathrm{p}=0.006 ; \mathrm{n}=400$ ) (Figure 3$)$. Abiotic conditions at the forest edges are extreme and many studies show these effects on the insect fauna (Wirth et al., 2008). Galling insects, as endogenous insects, are protected from desiccating factors and benefit from increased nutritional quality of their host plants when under stress (Price et al., 1998). Another pressure factor in this ecological system would be the higher abundance of natural enemies (herbivores, fungi and parasites) in wet habitats, but there was no differences in gall mortality amongst the four habitats sampled, demonstrating the absence of any differential

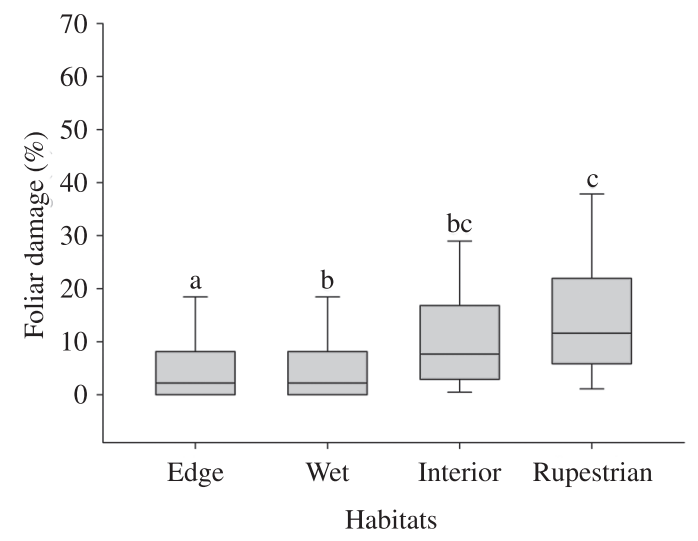

Figure 2. Leaf damage (\% leaf area lost) caused by freefeeding herbivores in individuals of Cnidoscolus quercifolius from a tropical deciduous forest, northeastern Brazil. Kruskal-Wallis Test $(K=34.16$; $\mathrm{DF}=3 ; \mathrm{p}=0.011 ; \mathrm{n}=400)$. The line indicates the median, boxes quartiles (25\%-75\%), bars are maximum and minimum values. The different letters represent statistical differences in the Dunn multiple comparison test $(\mathrm{p}<0.05)$. 


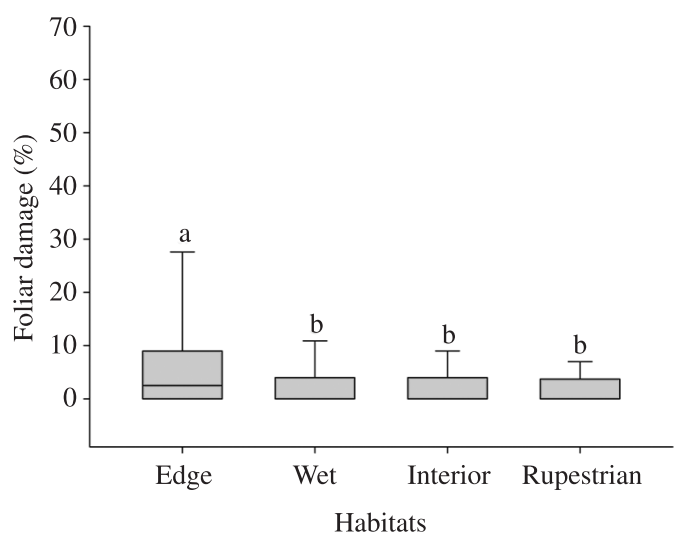

Figure 3. Galls abundance caused by an insect belonging to the Cecidomyiidae family on individuals of Cnidoscolus quercifolius from a tropical deciduous forest, northeastern Brazil. Kruskal-Wallis Test $(K=12.56$; DF $=3$; $\mathrm{p}=0.005 ; \mathrm{n}=400)$. The line indicates the median, boxes quartiles $(25 \%-75 \%)$, bars are maximum and minimum values. The different letters represent statistical differences in the Dunn multiple comparison test $(\mathrm{p}<0.05)$.

trophic selective pressure $(K=2.51, \mathrm{DF}=3, \mathrm{p}=0.47$; $\mathrm{n}=400$ ). Trophic relationships are not related to distribution patterns among habitats of two insect guilds associated with C. quercifolius. In addition, C. quercifolius individuals located at the edge habitat had high gall abundance, which confirms the pattern found (Root, 1973; Gonçalves-Alvim and Fernandes, 2001; Cuevas-Reyes et al., 2004; MSCoelho personal observation).

Although diverse, few studies are dedicated to tropical dry forests compared to tropical rainforests (Quesada et al., 2009). Even rarer are studies about herbivory patterns, as well as their mechanisms (Janzen, 1981, 1987; Neves et al., 2010). Our results demonstrated that environmental heterogeneity of dry forests can significantly alter important ecological interactions and experimental studies are needed to better understand such mechanisms responsible for differences in herbivory among habitats.

Acknowledgements - We thank the Universidade Federal de Pernambuco for the logistical support. We also thank Dra. Inara Roberta Leal and Dr. Marcelo Tabarelli for excellent contributions during the course Ecologia da Caatinga and Procad/Capes 0166-01, international cooperation program 002/09 and FAPEMIG for their financial support.

\section{References}

ANDOW, DA., 1991. Vegetational diversity and arthropod population response. Annual review of entomology, vol. 36, p. 561. http://dx.doi.org/10.1146/annurev.en.36.010191.003021

BELOVSKY, GE. and SLADE, JB., 2003. Effects of insects on primary production in temperate herbaceous communities: a meta-analysis. Ecological Entomology, vol. 28, p. 511-521. http://dx.doi.org/10.1046/j.1365-2311.2003.00540.x

BLANCHE, KR., 2000. Diversity of insect-induced galls along a temperature-rainfall gradient in the tropical savannah region of the Northern Territory, Australia. Austral Ecology, vol. 25, p. 311-318. http://dx.doi.org/10.1046/j.1442-9993.2000.01040.x

BLANCHE, KR. and LUDWING, JA., 2001. Species richness of gall-inducing insects and host plants along altitudinal gradient in Big Bend National Park, Texas. American Midland Naturalist, vol. 145, p. 219-232. http://dx.doi.org/10.1674/0003-0031(2001)145[0219:SR OGII]2.0.CO;2

BJÖRKMAN, C., 2000. Interactive effects of host resistance and drought stress on the performance of a gall-making aphid living on Norway spruce. Oecologia, vol. 123, p. 223-231. http://dx.doi. org/10.1007/s004420051009

CARSON, WP. and ROOT, RB., 2009. Top-down effects of insect herbivores during early succession: influence on biomass and plant dominance. Oecologia, vol. 121, p. 260-272.

CUEVAS-REYES, P., QUESADA, M., HANSON, P., DIRZO, R. and OYAMA, K., 2004. Diversity of gall-inducing insects in a Mexican tropical dry forest: the importance of plant species richness, life-forms, host plant age and plant density. Journal of Ecology, vol. 92, p. 707-716. http://dx.doi.org/10.1111/j.00220477.2004.00896.x

COLEY, PD. and BARONE, JA., 1996. Herbivory and plant defenses in tropical forests. Annual Review of Ecology and Systematics, vol. 27, p. 305-335. http://dx.doi.org/10.1146/ annurev.ecolsys.27.1.305

CORNELISSEN, T. and STILING, p., 2009. Spatial, bottom-up, and top-down effects on the abundance of leaf miner. Ecography, vol. 32, p. 459-467. http://dx.doi.org/10.1111/j.1600-0587.2008.05590.x

CONNELL, JH., TRACEY, JG. and WEBB, LJ., 1984. Compensatory recruitment, growth and mortality as factors maintaining rain forest tree diversity. Ecological Monographs, vol. 54, p. 141- 64. http://dx.doi.org/10.2307/1942659

FERNANDES, GW. and LARA, ACF., 1993. The Geography of galling insects and the mechanisms that result in patterns. In: PRICE, PW., MATTSON, WJ. and BARANCHIKOV, YN. The ecology and evolution of gall-forming insects. United States Department of Agriculture. p. 42-47. General Technical Report NC-174.

FERNANDES, GW. and PRICE, PW., 1988. Biographical gradients in galling species richness. Test of hypotheses. Oecologia, vol. 76, p. 161-167.

-, 1992. The adaptative significance of insect gall distribution: survivorship of species in xeric and mesic habitats. Oecologia, vol. 90, p. 14-20. http://dx.doi.org/10.1007/BF00317803

GASTON, KJ. and HUDSON, E., 1994. Regional patterns of diversity and estimates of global insect species richness. Biodiversity and Conservation, vol. 3, p. 493-500. http://dx.doi. org/10.1007/BF00115155

GONÇALVES-ALVIM, SJ. and FERNANDES, GW., 2001. Biodiversity of galling insects: historical, community and habitat in four neotropical savannas. Biodiversity and Conservation, vol. 10, p. 79-98. http://dx.doi.org/10.1023/A:1016602213305

GRATTON, C. and DENNO, RF., 2003. Seasonal shift from bottom-up to top-down impact in phytophagous insect populations. Oecologia, vol. 134, p. 487-495. PMid:12647120.

HERMS, DA. and MATTSON WJ., 1992. The dilemma of plants - to grow or defend. Quarterly review of biology, vol. 67, p. 283-335. http://dx.doi.org/10.1086/417659 
HEYWOOD, VH., 1995. Global biodiversity assessment. Cambridge: United Nations Environmental Program, Cambridge University Press.

JANZEN, DH., 1970. Herbivores and the number of tree species in tropical forests. American Naturalist, vol. 104, p. 501-28. http:// dx.doi.org/10.1086/282687

-, 1981. Patterns of herbivory in a tropical deciduous forest. Biotropica, vol. 13, p. 271-282. http://dx.doi.org/10.2307/2387805

-, 1987. Insect diversity of a Costa Rican dry forest: why keep it, and how? Biological Journal of Linnean Society, vol. 30, p. 343-356 http://dx.doi.org/10.1111/j.1095-8312.1987.tb00307.x

JACTEL, H. and BROCKERHOFF, EG., 2007. Tree diversity reduces herbivory by forest insects. Ecology Letters, vol. 10, p. 835-848. PMid:17663717. http://dx.doi.org/10.1111/j.14610248.2007.01073.x

LANDSBER, J. and OHMART, C., 1989. Levels of insect defoliation in forests - Patterns and Concepts. Trends in Ecology \& Evolution, vol. 4, p. 96-100 . http://dx.doi.org/10.1016/01695347(89)90054-2

LARA, ACF., FERNANDES, GW. and GONÇALVES-ALVIM, SJ., 2002. Tests of hypotheses on patterns of gall distribution along an altitudinal gradient. Tropical Zoology, vol. 15, p. 219-232.

LEWINSOHN, TM., NOVOTNY, V. and BASSET, Y., 2005. Insects on plants: Diversity of Herbivore Assemblages Revisited. Annual review of ecology and systematics, vol. 36, p. 597-620. http://dx.doi.org/10.1146/annurev.ecolsys.36.091704.175520

LEWINSOHN, TM. and ROSLIN, t., 2008. Four ways towards tropical herbivore megadiversity. Ecology Letters, vol, 11, p. 398-416. PMid:18248447. http://dx.doi.org/10.1111/j.14610248.2008.01155.x

McNAUGHTON, SJ.; OESTERHELD, M.; FRANK, DA. and WILLIAMS, KJ., 1989. Ecosystem-level patterns of primary productivity and herbivory in terrestrial habitats. Nature, vol. 341, p. 142-144. PMid:2779651. http://dx.doi.org/10.1038/341142a0

MAIA, GN., 2004. Caatinga: árvores e arbustos e suas utilidades. São Paulo: D\&Z. 413 p.

MENDONÇA, MS., 2001. Galling insect diversity: the resource synchronisation hypothesis. Oikos, vol. 95, p. 171-176. http:// dx.doi.org/10.1034/j.1600-0706.2001.950120.x

MULDER, CPH., KORICHEVA, J., HUSS-DANELL, K., HOEGBERG, P. and JOSHI, J., 1999. Insects affect relationships between plant species richness and ecosystem processes. Ecology Letters, vol. 2, p. 237-246. http://dx.doi.org/10.1046/j.14610248.1999.00070.x

NEVES, FS., ARAÚJO, LS., ESPÍRITO-SANTO, MM., FAGUNDES, M., FERNANDES, GW., SANCHEZ-AZOFEIFA, GA. and QUESADA, M., 2010. Canopy herbivory and insect herbivore diversity in a dry forest-savana transition in Brazil. Biotropica, vol. 42, p. 112-118. http://dx.doi.org/10.1111/j.17447429.2009.00541.x

PRESZLER, RW. and PRICE, PW., 1988. Host quality and sawfly populations: a new approach to life table analysis. Ecology, vol. 69, p. 2012-2020. http://dx.doi.org/10.2307/1941179

PRICE, PW., FERNANDES, GW., LARA, ACF., BRAWN, J., BARRIOS, H., WRIGHT, MG., RIBEIRO, SP. and ROTHCLIFF, N., 1998. Global patterns in local number of insect galling species. Journal of Biogeography, vol. 25, p. 581-591. http://dx.doi. org/10.1046/j.1365-2699.1998.2530581.x
PRICE, PW., FERNANDES, GW. and WARING, GL., 1987. Adaptative Nature of Insect Galls. Environmental Entomology, vol. 16, p. 15-24.

QUESADA, M., SANCHEZ-AZOFEIFA, GA., ALVAREZAÑORVE, M., STONER, KE., AVILA-CABADILLA, L., CALVO-ALVARADO, J., CASTILLO, A., ESPÍRITO-SANTO, MM., FAGUNDES, M., FERNANDES, GW., GAMON, J., LOPEZARAIZA-MIKEL, M., LAWRENCE, D., MORELLATO, LPC., POWERS, JS., NEVES, FS., ROSAS-GUERREIRO, V., SAYAGO, R. and SANCHEZ-MONTOYA, G., 2009. Succession and management of tropical dry forests in the Americas: review and new perspectives. http://dx.doi.org/10.1016/j.foreco.2009.06.023Forest Ecology and Management, vol. 258, p. 1014-1024.

RIBEIRO, SP. and BASSET, Y., 2007. Gall-forming and freefeeding herbivory along vertical gradients in a lowland tropical rainforest: the importance of leaf sclerophylly. Ecography, vol. 30, p. 663-672. http://dx.doi.org/10.1111/j.2007.0906-7590.05083.x

RIBEIRO FILHO, NMR., CALDEIRA, VPS., FLORÊNCIO, IM., AZEVEDO, DO. and DANTAS, JP., 2007. Avaliação comparada dos índices químicos nitrogênio e fósforo nas porções morfológicas das espécimes de faveleira com espinhos e sem espinhos. Revista Brasileira de Produtos Agroindustriais, vol. 9, p. 149-160.

RIZZINI, CT., 1979. Tratado de fitogeografia do Brasil. São Paulo: HUCITEC. 374 p.

ROOT, RB., 1973. Organization of a plant-arthropod association in simple and diverse habitats: the fauna of collards (Brassica oleraceae). Ecological Monographs, vol. 43, p. 95-124. http:// dx.doi.org/10.2307/1942161

STRAUSS, SY. and AGRAWAL, AA., 1999. The ecology and evolution of plant tolerance to herbivory. Trends in Ecology \& Evolution, vol. 14, p. 179-185. http://dx.doi.org/10.1016/S01695347(98)01576-6

SILVA, FBR., RICHÉ, GR., TONNEAU, JP., SOUZA-NETO, NC., BRITO, LTL., CORREIA, RC., CAVALCANTI, AC., SILVA, FHBB., SILVA, AB., ARAÚJO-FILHO, JC. and LEITE, AP., 2000. Zoneamento Agroecológico do Nordeste: diagnóstico e prognóstico. Recife: Embrapa Solos/Escritório Regional de Pesquisa e desenvolvimento do Nordeste (ERP/NE). Embrapa Semi-Árido, CD-ROM. Embrapa Solos - Documento no. 14, Petrolina.

VELDTMAN, R. and McGEOCH, MA., 2003. Gall-forming insect species richness along a non-scleromorphic vegetation rainfall gradient in South Africa: The importance of plant community composition. Austral Ecology, vol. 28, p. 1-13. http://dx.doi. org/10.1046/j.1442-9993.2003.01234.x

WIRTH, R., MEYER, ST., LEAL, IR. and TABARELLI, M., 2008. Plant Herbivore Interactions at the Forest Edge. Progress in Botany, vol. 69, p. 423-448. http://dx.doi.org/10.1007/978-3540-72954-9_17

WRIGHT, MG. and SAMWAYS, MJ., 1996. Gall- insect species richness in African Fynbos and Karoo vegetation: the importance of plant species richness. Biodiversity Letters, vol. 3, p. 151-155. http://dx.doi.org/10.2307/2999733

-, 1998. Insect species richness tracking plant species richness in a diverse flora: gall-insect in the Cape Floristic Region, South Africa. Oecologia, vol. 115, p. 427-433. http://dx.doi.org/10.1007/ s004420050537

ZAR, JH., 1999. Biostatistical analysis. Upper Saddle River: Prentice Hall. 
